\title{
SISTEM PEMASARAN BERAS DI KECAMATAN CIBEBER, KABUPATEN CIANJUR
}

\author{
Alexandro Ephannuel Saragih ${ }^{1)}$, dan Netti Tinaprilla ${ }^{2)}$ \\ ${ }^{1,2)}$ Departemen Agribisnis, Fakultas Ekonomi dan Manajemen, Institut Pertanian Bogor \\ 1)alexandroesaragih@gmail.com
}

\begin{abstract}
Rice is the basic commodity that becomes the staple food for Indonesian. The objectives of this research were to analyse marketing channels, function, structure and marketing institutions of rice farmer in Cibeber Subdistrict. In addition, the purposes of this research were to analyse the marketing efficiency using the marketing margin, farmer's share and benefit cost ratio approaches. The research was conducted in 3 villages in Cisalak, Karangnunggal, Salamnunggal involving 30 farmers as respondents. 7 marketing institutions and 10 marketing channels are in the subdistrict. Generally, market structure in this subdistrict is oligopsonistic. Based on the marketing function and the profitable ratio of marketing cost, the most efficient channel is through farmers-middlemen-major collector and rice mills in village-retailerconsumer rice in Jakarta. The farmer should have made farmer groups as part of their marketing system in order to improve the bargaining position and easier capitalization through the warehouse system in Cianjur.
\end{abstract}

Keyword(s): Efficiency, Farmer' Share, Marketing Margin, Rice

\begin{abstract}
ABSTRAK
Beras merupakan komoditi utama yang menjadi pangan pokok bagi sebagian besar penduduk Indonesia. Tujuan penelitian adalah menganalisis saluran pemasaran, fungsi, struktur, dan perilaku lembaga-lembaga pemasaran beras di Kecamatan Cibeber. Selain itu, penelitian bertujuan menganalisis efisiensi saluran pemasaran berdasarkan pendekatan marjin, farmer's share dan rasio keuntungan terhadap biaya pemasaran. Berdasarkan penelitian di 3 desa sampel yakni Cisalak, Karangnunggal dan Salamnunggal dengan jumlah responden sebanyak 30 petani sampel. Terdapat 7 lembaga pemasaran dan 10 saluran pemasaran di kecamatan ini. Secara umum, struktur pasar beras di kecamatan ini adalah oligopsoni. Berdasarkan fungsi pemasaran dan rasio keuntungan terhadap biaya pemasaran, saluran yang melalui petanitengkulak-pengumpul besar dan pabrik beras-pengecer-konsumen di Jakarta merupakan saluran paling efisien secara keseluruhan. Petani sebaiknya menjadikan kelompok tani sebagai bagian dari sistem pemasaran untuk meningkatkan posisi tawar dan mempermudah pemodalan melalui sistem resi gudang yang berada di Cianjur
\end{abstract}

Kata Kunci: Efisiensi, Beras, Farmer's Share, Marjin Pemasaran

\section{PENDAHULUAN \\ Latar Belakang \\ Ketersediaan beras menjadi pen- ting untuk diperhatikan karena beras telah menjadi kebutuhan pokok bagi}

masyarakat Indonesia secara umum. Indonesia merupakan negara dengan jumlah penduduk terbanyak keempat saat ini di dunia. Penduduk Indonesia diproyeksikan sekitar 261 juta orang 
pada tahun 2020 (BPS, 2013). Konsumsi per kapita penduduk mencapai $139 \mathrm{~kg}$ (BPS, 2012) dan Indonesia merupakan salah satu negara dengan tingkat konsumsi tertinggi di dunia. Padahal, dilihat dari pertumbuhan luas lahan, produktivitas, dan tingkat produksi gabah seperti pada Lampiran 1, Indonesia memiliki tingkat pertumbuhan yang lambat. Hal ini mengimplikasikan dibutuhkannya usaha-usaha, temasuk dari pemerintah, untuk meningkatkan produksi beras Indonesia. Namun, usaha peningkatan produksi tentunya harus diikuti sistem pemasaran yang efektif dan efisien, sehingga dapat memotivasi petani utamanya sebagai produsen. Selain aspek produksi, pemasaran merupakan komponen penting dalam menciptakan aksesibilitas masyarakat terhadap beras (Swastika dan Sumaryanto dalam Lokollo, 2012).

Menurut Sultana (2012), program peningkatan produksi beras tidak akan dapat berjalan dengan efektif apabila sistem pemasaran tidak efisien. Pemasaran harus mampu berorientasi kepada kepuasan konsumen dan memberikan keuntungan kepada petani, pedagang, pengolah, dan lembaga pemasaran yang terlibat. Petani, dalam mengambil keputusan, harus memiliki informasi pasar yang baik. Keuntungan dan kerugian dari saluran dan strategi pemasaran yang berbeda, harus dipahami oleh petani.

Menurut Bassey et al. (2013), selain peningkatan kualitas beras, pemasaran beras di Nigeria membutuhkan strategi untuk efisiensi biaya transportasi dan penyimpanan. Hal ini diperlukan untuk dapat bersaing dengan beras impor.
Artinya, biaya pemasaran sangat mempengaruhi daya saing beras sebagai komoditi pertanian.

Proporsi pengeluaran masyarakat terhadap pembelian padi-padian bernilai sangat besar dibandingkan proporsi untuk pembelian komoditi lainnya sebagai sumber pangan. Pengeluaran penduduk Indonesia untuk konsumsi padi-padian mencapai 6,83 persen dari total pengeluarannya pada September 2014 (BPS, 2014). Hal ini berarti penduduk Indonesia masih bergantung pada beras sebagai pemenuhan pangan pokoknya.

Provinsi Jawa Barat merupakan salah satu lumbung padi di Indonesia. Pada tahun 2013 produksi padi di Jawa Barat mencapai 12.083.162 ton dari 71.279.709 ton total produksi nasional (BPS, 2013). Kabupaten Cianjur sendiri menjadi penyumbang yang cukup besar dibandingkan 25 kota dan kabupaten lainnya untuk jumlah produksi padi di Provinsi Jawa Barat tersebut yakni mencapai 925.996 ton pada tahun 2013 (Dinas Pertanian Cianjur, 2013 ${ }^{\mathrm{a}}$ ). Keunggulan tersebut, seharusnya mendapatkan penanganan pasca produksi yang baik dan efisien sehingga harga beli oleh konsumen tidak memberatkan mereka dan di sisi lain petani tetap mendapatkan keuntungan yang mampu mendorongnya meningkatkan skala usahanya.

\section{Perumusan Masalah}

Para petani padi di Kabupaten Cianjur secara umum memiliki posisi tawar yang rendah saat memasarkan hasil panennya. Hal ini disebabkan 
sebahagian besar petani masih hanya menjual gabah kering panen dan skala usaha masih kecil. Saat akan memasarkan hasil panennya, petani cenderung ingin praktis menjual hasil panennya dalam bentuk gabah kering panen (GKP). Dengan keadaan tersebut, petani masih sangat bergantung kepada pemilik modal yang dapat mengolah hasil panennya tersebut.

Petani di Kabupaten Cianjur pada umumnya memiliki kendala lain dalam proses pemasaran, seperti keterbatasan sarana dan prasarana, transportasi dalam distribusi, teknologi, dan informasi pasar. Kondisi ini menyebabkan petani tidak dapat mengontrol harga secara berkelanjutan dan transmisi harga menjadi tidak seimbang (Nurdiyah, 2014). Gabah kering panen padi (GKP) di tingkat petani berfluktuasi sekitar $\mathrm{Rp}$ 3.000-Rp 4.000/kg dan masih cukup jauh dari rata-rata harga berasnya di pasar yakni Rp 8.533/kg (Dinas Pertanian Cianjur, 2013 ${ }^{\text {b }}$ ) sehingga diperlukan analisis untuk memeriksa manfaat dan biaya yang dikeluarkan setiap lembaga yang terlibat.

Kelompok tani yang terbentuk di Kabupaten Cianjur pada umumnya belum dapat menjalankan fungsi pemasaran dengan baik. Hal ini dilihat dari kemampuan kelompok tani menghimpun dan memasarkan hasil panen anggotanya. Terdapat sistem resi gudang di Kabupaten Cianjur, yang berusaha meningkatkan kemampuan pemodalan bagi para petani di Cianjur, dengan harapan dapat meningkatkan posisi tawar petani. Namun, hal ini sering terkendala bagi petani karena hasil panen masing-masing petani tidak memenuhi syarat. Fungsi kelompok tani sebagai lembaga pemasaran belum berjalan efektif. Pihak gudang menerima hasil panen petani dengan syarat GKP minimal 10 ton. Selain itu, kualitas atau rendemen gabah dari petani juga masih belum bisa konsisten akibat perubahan musim dan gangguan hama. Idealnya, nilai konversi GKP ke gabah kering giling (GKG) sebesar 86,02 persen dan GKG ke beras sekitar 62,74 persen (Dinas Pertanian Cianjur, 2013 ${ }^{\mathrm{c}}$ ). Namun, hal ini masih sering tidak konsisten dicapai akibat rendahnya kualitas gabah petani.

Kecamatan Cibeber merupakan salah satu daerah unggulan tanaman pangan komoditas padi dengan menggunakan sistem irigasi pedesaan di Kabupaten Cianjur menurut Surat Keputusan Bupati Nomor 520/KEP.240DISTAN/2012 tentang perwilayahan tanaman pangan dan hortikultura. Hal ini ditunjukkan dari jumlah gabah kering panen (GKP) pada tahun 2013 mencapai 52.582 ton (Dinas Pertanian Cianjur, $2013^{\mathrm{d}}$ ). Kondisi ini menggambarkan bahwa daerah ini menjadi salah satu daerah di Kabupaten Cianjur yang penting dan potensial dalam berpartisipasi pada pemasaran beras di Cianjur dan daerah lain. Produksi di daerah ini tentunya membutuhkan penanganan pasca produksi, yakni proses pemasaran yang efisien.

Beras sebagai makanan pokok di Indonesia mengimplikasikan bahwa beras harus disediakan dengan jumlah, waktu, dan harga yang tepat. Hal ini mendasari pentingnya penelitian 
mengenai pemasaran komoditi atau pangan tersebut. Hal yang akan dibahas adalah:

1. Bagaimana saluran pemasaran beras dan fungsi-fungsi pemasaran yang dilakukan oleh lembagalembaga pemasaran di Kecamatan Cibeber, Kabupaten Cianjur, Provinsi Jawa Barat?

2. Bagaimana struktur dan perilaku pasar pada masing-masing lembaga yang terlibat?

3. Bagaimana tingkat efisiensi saluran pemasaran beras di Kecamatan Cibeber dengan pendekatan marjin pemasaran, farmer's share serta rasio keuntungan dan biaya?

\section{Tujuan Penelitian}

Berdasarkan perumusan masalah maka tujuan dari penelitian ini adalah:

1. Menganalisis saluran, fungsi, struktur dan perilaku lembagalembaga pemasaran beras di Kecamatan Cibeber, Kabupaten Cianjur.

2. Membandingkan efisiensi operasional pada setiap saluran pemasaran beras di Kecamatan Cibeber dengan pendekatan marjin pemasaran, farmer's share serta rasio keuntungan dan biaya.

\section{KERANGKA PEMIKIRAN}

\section{Konsep Pemasaran}

John Philips dalam Asmarantaka $\left(2012^{a}\right)$ mendefenisikan pemasaran pertanian adalah semua aktivitas perdagangan yang meliputi aliran barangbarang dan jasa-jasa secara fisik dari pusat produksi pertanian ke pusat konsumsi pertanian. Dalam pemasaran pertanian tersebut terdapat perpindahan kepemilikan yang menciptakan kegunaan waktu (time utility), tempat (place utility), bentuk (form utility) terhadap komoditi-komoditi pertanian.

\section{Konsep Lembaga, Saluran dan Fungsi Pemasaran}

Khols dan Uhls (2002 $)$ menjelaskan bahwa lembaga pemasaran adalah badan-badan yang menyelenggarakan kegiatan atau fungsi fungsi pemasaran dimana barang bergerak dari produsen sampai ke konsumen akhir. Lembaga pemasaran ini bisa termasuk golongan produsen, pedagang perantara, dan lembaga pemberi jasa.

Menurut Limbong dan Sitorus dalam Sudiyono $\left(2002^{\mathrm{a}}\right)$, saluran pemasaran merupakan himpunan perusahaan dan perorangan yang mengambil alih hak atau membantu mengalihkan hak atas barang atau jasa tertentu selama barang atau jasa tertentu berpindah dari produsen hingga ke konsumen.

Fungsi pemasaran didefenisikan sebagai serangkaian aktivitas fungsional yang dilakukan oleh lembaga-lembaga pemasaran, baik proses aktivitas fisik maupun proses jasa, yang ditujukan untuk memberikan kepuasan kepada konsumen sesuai dengan kebutuhan dan keinginannya melalui penciptaan atau penambahan kegunaan bentuk, waktu, tempat, dan kepemilikan terhadap suatu produk (Sudiyono, 2002 ${ }^{\mathrm{b}}$ ). 


\section{Konsep Efisiensi Pemasaran}

Menurut Khols dan Uhls (1990), efisiensi pemasaran dapat dibagi menjadi:

1. Efisiensi operasional, peningkatan efisiensi pemasaran akibat perubahan biaya penyelengaraan fungsi pemasaran tanpa mempengaruhi sisi output. Artinya, efisiensi operasional diukur berdasarkan biaya pemasaran dan marjin pemasaran, dimana biaya dan marjin tersebut lebih rendah tanpa mengurangi kepuasan konsumen.

2. Efisiensi harga, yaitu pendekatan untuk melihat kemampuan sistem pasar dalam mengalokasikan sumberdaya dan memaksimumkan output. Efisiensi harga diukur melalui korelasi harga yang terjadi pada berbagai tingkat pasar. Korelasi harga diperoleh dari integrasi pasar. Integrasi pasar menjelaskan seberapa jauh harga komoditas pada suatu tingkat lembaga pemasaran dipengaruhi oleh harga pada tingkat lembaga pemasaran lainnya.

Penelitian ini hanya membahas efisiensi operasional pemasaran.

\section{Konsep Structure, Conduct, Performance (SCP)}

Pendekatan SCP pertama kali diperkenalkan oleh Edward S Mason dan dikembangkan oleh Joe S Bain pada tahun 1940 dalam buku Industrial Organization (Purcell, 1979). Kemudian konsep ini terus berkembang dan banyak digunakan dalam analisis pemasaran, baik barang industri maupun pertanian (Melania, 2007).
Menurut Baye (2010), paradigma SCP terdiri dari 3 aspek yang berhubungan. Identifikasi struktur pasar (market structure) terdiri dari berapa jumlah perusahaan yang bersaing di pasar, penggunaan teknologi, konsentrasi pasar, kondisi pasar, dan hambatan keluar masuk pasar. Sedangkan perilaku pasar (market conduct) merupakan bentuk perilaku terhadap struktur pasar yang terjadi. Indikatornya seperti proses penentuan harga, kegiatan integrasi dan merger, penentuan periklanan, dan penentuan research and development. Kinerja pasar (market peformace) merupakan keuntungan dan social welfare yang diterima industri dalam suatu pasar. Menurut Dahl dan Hammond $\left(1977^{\mathrm{a}}\right)$, kinerja pasar merupakan akibat dari struktur dan perilaku pasar yang ditunjukkan dengan harga, biaya, dan volume produksi sebagai dasar penilaian sitem pemasaran. Struktur, perilaku, dan kinerja pasar tidak selalu berinteraksi secara linear, tetapi saling mempengaruhi. Beberapa elemen kinerja pasar seperti marjin pemasaran, farmer share, rasio keuntungan terhadap biaya pemasaran, dan integrasi pasar.

\section{Konsep Struktur Pasar}

Struktur pasar merupakan salah satu elemen penting dalam melakukan analisis pemasaran. Menurut Dahl dan Hammond $\left(1977^{b}\right)$, terdapat empat faktor penentu dari karakteristik struktur pasar, yaitu (1) jumlah dan ukuran penjual dan pembeli, (2) keadaan produk yang diperjualbelikan, (3) kemudahan masuk dan keluar pasar, (4) pengetahuan 
konsumen terhadap harga dan struktur biaya produksi.

Ditinjau dari sisi penjualan, maka struktur pasar dibedakan menjadi: (1) pasar persaingan sempurna, (2) persaingan monopolistik, (3) oligopoli, (4) monopoli. Sedangkan dari sisi pembeli, maka struktur pasar dapat dibedakan menjadi :(1) pasar persaingan sempurna, (2) olipgosonistik, (3) olipgosoni, (4) monopsoni.

Pengoptimuman efisiensi pemasaran dapat dilakukan dengan kriteria struktur pasar sebagai berikut: (1) ukuran jumlah pembeli dan penjual harus banyak sehingga menjamin adanya suatu intensitas persaingan yang memadai dalam hal harga dan kualitas produk, (2) adanya kebebasan masuk dan keluar pasar bagi lembaga-lembaga pemasaran, (3) jumlah pembeli harus memadai sehingga mendorong peningkatan efisiensi investasi dalam usaha pemasaran komoditi pertanian.

\section{Konsep Perilaku Pasar}

Analisis efisiensi pemasaran berdasarkan tingkah laku pasar adalah bagaimana peserta pasar, yaitu produsen, konsumen dan lembaga pemasaran menyesuaikan diri terhadap situasi penjualan dan pembelian yang terjadi. Dalam menganalisis tingkah laku pasar ini maka terdapat tiga pihak peserta pasar yang mempunyai kepentingan berbeda. Tingkah laku pasar dapat semakin efisien dengan adanya (Sudiyono, 2002 ${ }^{\mathrm{c}}$ ):

1. Praktek-praktek penentuan harga harus memungkinkan adanya grading dan standarisasi komoditi pertanian
2. Biaya pemasaran harus seragam

3. Penentuan harga harus bebas dari praktek-praktek kerjasama yang tidak jujur

4. Intervensi pemerintah dalam bentuk kebijakan harga harus dapat memperbaiki mutu produk dan peningkatan keputusan konsumen.

\section{Marjin Pemasaran}

Marjin pemasaran dapat didefenisikan dengan dua cara, yaitu: Pertama, marjin pemasaran merupakan perbedaan antara harga yang dibayarkan konsumen dengan harga yang diterima petani (Daly dalam Asmarantaka, 2012 ${ }^{\mathrm{b}}$ ). Kedua, marjin pemasaran merupakan biaya dari jasa-jasa pemasaran yang dibutuhkan sebagai akibat permintaan dan penawaran dari jasa-jasa pemasaran (Waite dan Trelogan dalam Asmarantaka, 2012 ${ }^{\mathrm{c}}$ ).

Apabila dalam pemasaran suatu produk pertanian, terdapat lembagalembaga yang melakukan fungsi-fungsi pemasaran, maka marjin pemasaran secara matematis dapat ditulis sebagai:

dimana:

$$
\mathrm{M}=\sum_{t=1}^{m} \sum_{j=1}^{n} \mathrm{Cij}+\sum \boldsymbol{\pi} \mathbf{j}
$$

$\mathrm{M}=$ marjin pemasaran

$\mathrm{Cij}=$ biaya pemasaran untuk melaksanakan fungsi pemasaran ke-i oleh lembaga pemasaran ke-j

$\boldsymbol{\pi} \mathbf{j}=$ keuntungan yang diperoleh lembaga pemasaran ke-j

$\mathrm{m}=$ jumlah jenis biaya pemasaran

$\mathrm{n} \quad=$ jumlah lembaga pemasaran

Permintaan konsumen atas suatu produk di tingkat pengecer disebut permintaan primer. Permintaan suatu produk di tingkat petani disebut permintaan turunan sebab permintaan ini diturunkan dari permintaan konsumen di tingkat pengecer. 


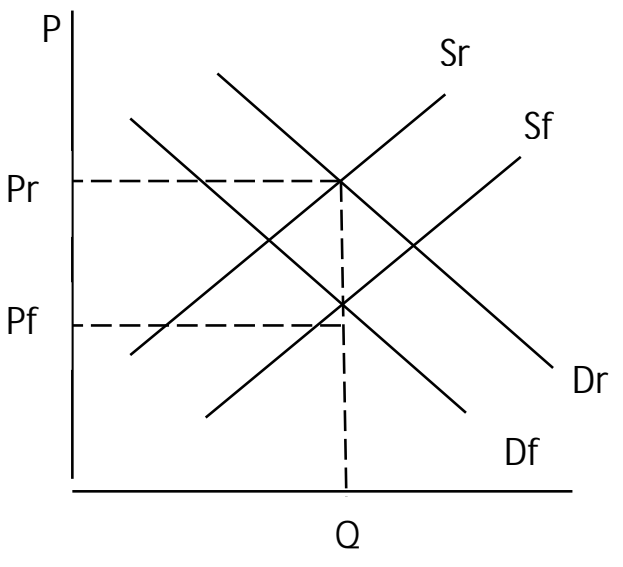

Keterangan :

$\mathrm{Q}=$ jumlah barang

$\mathrm{Pr}=$ harga tingkat eceran

$\mathrm{Pf}=$ harga tingkat petani

$\mathrm{Sr}=$ kurva penawaran tingkat pasar eceran

$\mathrm{Sf}=$ kurva penawaran tingkat petani

$\mathrm{Dr}=$ kurva permintaan tingkat pasar eceran

Df $=$ kurva permintaan tingkat petani

Sumber: Dahl dan Hammond (1977)

\section{Gambar 1. Kurva Marjin Pemasaran}

Berdasarkan sisi penawaran, penawaran primer adalah penawaran komoditi pertanian di tingkat petani. Penawaran primer ini biasanya berupa penawaran bahan mentah ataupun bahan baku sedangkan penawaran turunan adalah penawaran di tingkat pengecer.

Gambar 1 menginformasikan kurva permintaan primer yang berpotongan dengan kurva penawaran turunan membentuk harga di tingkat pengecer (pr). Sedangkan kurva permintaan turunan berpotongan dengan kurva penawaran primer membentuk harga di tingkat petani (pf). Marjin pemasaran sama dengan selisih harga di tingkat pengecer dengan harga di tingkat petani $(\mathrm{M}=\mathrm{Pr}-$ Pf).

Berdasarkan Gambar 1, dapat diukur nilai marjin pemasaran atau value of the marketing margin (VMM) yang dinikmati oleh lembaga-lembaga pemasaran yang terlibat dalam pemasaran komoditi pertanian. Nilai marjin pemasaran merupakan hasil kali antara perbedaaan harga di tingkat pengecer dengan harga di tingkat petani dengan jumlah yang ditransaksikan $(\mathrm{VMM}=(\mathrm{Pr}-$ Pf). Q).

Pemasaran melibatkan lembagalembaga pemasaran yang menjalankan proses bisnis dan fungsi pemasaran. Hal ini menggambarkan bahwa marjin pemasaran merupakan gambaran dari biaya pemasaran dan keuntungan lembaga pemasaran. Jumlah lembaga pemasaran yang terlibat dapat mempengaruhi besarnya marjin pemasaran.

Besarnya marjin pemasaran sering digunakan sebagai indikator efisiensi operasional saluran pemasaran. Marjin yang tinggi mempertimbangkan beberapa hal seperti: (1) penggunaan teknologi baru yang meningkatkan biaya produksi, (2) spesialisasi produksi yang menyebabkan meningkatkan biaya transportasi (3) kegunaan waktu dalam produk pertanian yang meningkatkan biaya penyimpanan dan pengolahan, (4) kecenderungan konsumen terhadap produk siap saji, (5) kenaikan upah pekerja (Sari, 2013). Artinya, marjin dipengaruhi oleh biaya pemasaran. Secara umum, marjin yang kecil menunjukkan nilai yang semakin efisien secara operasional. Namun, hal ini tidak mutlak karena mempertimbangkan kepuasaan dari produsen, lembaga-lembaga pemasaran, dan konsumen yang terlibat dalam saluran pemasaran. Pada dasarnya, marjin pemasaran harus menggambarkan 
aktivitas nilai tambah yang dilakukan oleh lembaga pemasaran.

\section{Konsep Farmer's Share}

Farmer's share dapat digunakan untuk menganalisis efisiensi pemasaran dari sisi penerimaan petani. Saluran yang efisien pada umumnya saat farmer's share saluran tersebut bernilai paling besar diantara saluran lain dan total marjin pemasarannya bernilai paling kecil. Ketentuan ini tidak selalu dapat diandalkan dengan mempertimbangkan fungsi-fungsi dan manfaat yang dihasilkan oleh lembaga-lembaga pemasaran dalam saluran tersebut.

Menurut Khols dan Uhls $\left(2002^{\mathrm{b}}\right)$, farmer's share adalah persentase harga yang diterima petani sebagai imbalan dari kegiatan usahatani yang dilakukannya dalam menghasilkan suatu komoditas. Nilai farmer's share ditentukan oleh besarnya rasio harga yang diterima oleh produsen terhadap harga yang yang dibayarkan oleh konsumen. Secara matematik dapat dirumuskan :

Keterangan :

Fs = farmer's share

Pf = harga di tingkat petani

Pr = harga di tingkat konsumen

\section{Konsep Rasio Keuntungan dan Biaya}

Tingkat efisiensi pemasaran dapat diukur melalui besarnya rasio keuntungan terhadap biaya pemasaran. Penyebaran rasio keuntungan dan biaya yang semakin merata, menunjukkan bahwa sistem pemasaran tersebut semakin efisien secara operasional (Dahl dan Hammond, $1977^{\circ}$ ).

\section{METODE PENELITIAN}

\section{Lokasi dan Waktu Penelitian}

Pemilihan lokasi penelitian dilakukan secara sengaja dengan pertimbangan tempat penelitian memiliki kesesuaian dengan topik yang akan dianalisis, yakni pemasaran dari hasil produksi gabah yang sangat besar di Kecamatan Cibeber. Lokasi penelitian berada di Kecamatan Cibeber, Kabupaten Cianjur, Provinsi Jawa Barat. Penelitian dilakukan di 3 desa sampel yang mewakili 18 desa di Kecamatan tersebut. Ketiga desa yang dipilih yakni Desa Salamnunggal, Karang nunggal ,dan Cisalak merupakan daerah yang yang memiliki jumlah produksi yang relatif lebih besar dibandingkan desa lainnya (Dinas Pertanian Cianjur, 2013 ${ }^{\mathrm{e}}$ ). Lokasi yang dipilih diharapkan mampu menggambarkan keadaaan umum pemasaran gabah atau beras dari Kecamatan Cibeber, Kabupaten Cianjur.

\section{Jenis dan Sumber Data}

Data yang digunakan dalam penelitian terdiri dari data primer dan sekunder. Data primer meliputi hasil wawancara dan observasi di lokasi penelitian. Data sekunder berasal dari studi literatur, buku-buku, hasil penelitian yang relevan, artikel terkait topik penelitian, data Dinas Pertanian Jawa Barat dan Cianjur, data Badan Penyuluh Pertanian Kecamatan Cibeber, data Badan Pusat Statistik Indonesia dan lain sebagainya. 
Pengambilan data menggunakan mengikuti alur pemasaran mulai dari petani sebagai produsen sampai ke tingkat konsumen. Dari tingkat petani akan diketahui aliran produk dan lembaga apa saja yang terlibat dalam proses pemasaran.

Tahap awal melibatkan masingmasing 10 orang petani dari desa sampel, sehingga terdapat total 30 petani yang terlibat sebagai responden awal. Petani yang dipilih merupakan petani padi dengan varietas Ciherang .Berikutnya proses wawancara melibatkan lembagalembaga pemasaran yakni 4 orang tengkulak, 1 penggiling, 2 pengumpul besar dan pabrik beras dalam desa, 1 pabrik beras dengan skala lebih besar diluar desa, 3 distributor di Cianjur, 3 distributor di Jakarta, 3 pengecer di Cianjur dan 3 pengecer di Jakarta.

\section{Metode Pengolahan Data}

Penghitungan indikator efisiensi operasional pemasaran mempertimbangkan bentuk komoditi yang berbeda dari produsen sampai ke konsumen akhir, yakni dari gabah menjadi beras. Oleh karena itu, nilai konversi digunakan dalam penghitungan dan dijadikan sebagai biaya penyusutan dalam biaya pemasaran. nilai konversi GKP ke GKG sebesar 86,02 persen dan GKG ke beras sekitar 62,74 persen (Dinas Pertanian Cianjur, 2013 ${ }^{\mathrm{f}}$.

\section{HASIL DAN PEMBAHASAN Identifikasi Saluran Pemasaran}

Saluran pemasaran secara umum merupakan serangkaian lembaga pema- saran yang mengambil alih hak atas barang dan jasa, dalam hal ini hasil panen padi varietas Ciherang, dimulai dari petani sebagai produsen sampai ke konsumen akhir. Pada penelitian ini, saluran pemasaran digambarkan oleh Gambar 2 dan 3.

Berdasarkan pengamatan di lapangan, terdapat 10 pola saluran pemasaran, yakni :

1. Petani-Tengkulak-RMU-PengecerKonsumen (di Cianjur)

2. Petani-RMU-Pengecer-Konsumen (di Cianjur)

3. Petani-Tengkulak-RMU-Konsumen (di Cianjur)

4. Petani-Tengkulak-Pengumpul Besar dan Pabrik Beras-DistributorPengecer-Konsumen (di Cianjur)

5. Petani-Tengkulak-Pengumpul Besar dan Pabrik Beras-DistributorKonsumen (di Cianjur)

6. Petani-Pengumpul Besar dan Pabrik Beras-Distributor-PengecerKonsumen (di Cianjur)

7. Petani-Pengumpul Besar dan Pabrik Beras-Distributor-Konsumen (di Cianjur)

8. Petani-Tengkulak-Pengumpul Besar dan Pabrik Beras-PengecerKonsumen (di Jakarta)

9. Petani-Tengkulak-Pengumpul Besar dan Pabrik Beras-Pabrik BerasDistributor-Pengecer-Konsumen (di Jakarta)

10.Petani-Pengumpul Besar dan Pabrik Beras-Pabrik Beras-DistributorPengecer-Konsumen (di Jakarta) 
Seluruh saluran dimulai dari tingkat petani yang kemudian melakukan penjualan ke 3 lembaga yang berbeda, yakni tengkulak, rice milling unit (RMU) atau penggilingan, pengumpul besar dan pabrik beras. Berdasarkan volume penjualan, penjualan petani ke 3 setiap lembaga tersebut adalah 51,98 ton beras $(96,47 \%), 0,78$ ton beras $(1,45 \%)$ dan 2,08 ton beras $(2,08 \%)$. Terdapat 24 orang petani yang menjual hasil panennya melalui tengkulak, 3 orang petani langsung ke RMU dan 3 orang langsung ke pengumpul besar dan pabrik beras. Pada identifikasi saluran pemasaran ini, volume produk yang

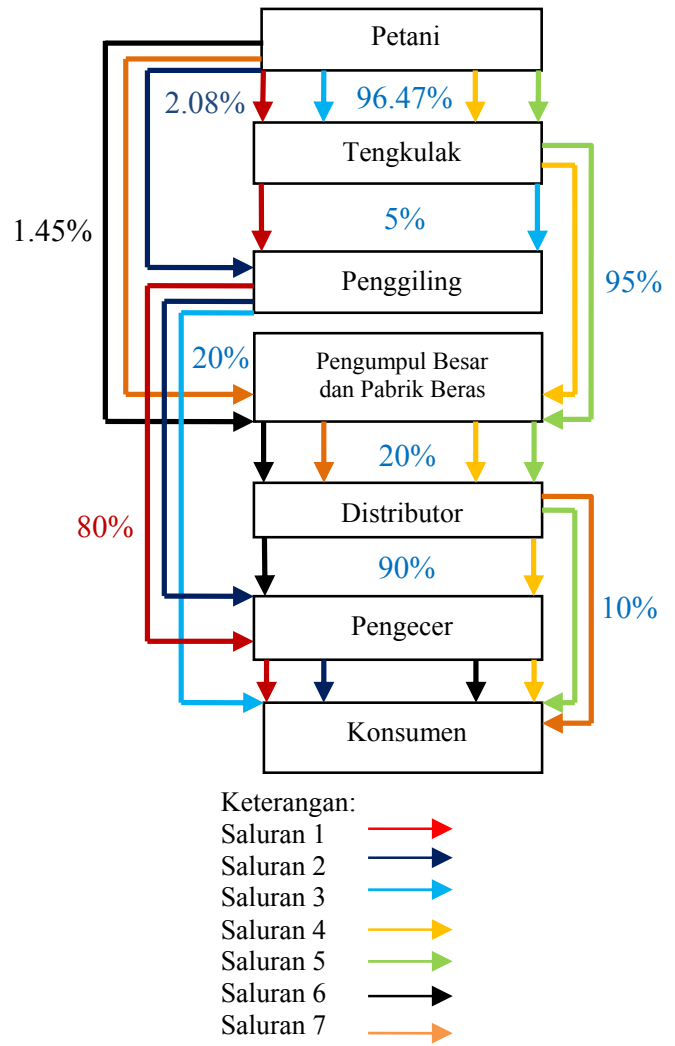

Gambar 2. Saluran Pemasaran Beras di Kecamatan Cibeber dengan Konsumen Akhir di Cianjur mengalir pada seluruh lembaga merupakan volume beras.

\section{Analisis Fungsi Pemasaran}

Fungsi pemasaran secara umum merupakan aktivitas bisnis yang terjadi atau proses dalam sistem pemasaran yang akan meningkatkan dan atau menciptakan nilai untuk memenuhi kepuasan konsumen. Berdasarkan pendekatan fungsi, terdapat beberapa fungsi dalam pemasaran yakni fungsi pertukaran, fungsi fisik dan fungsi fasilitas. Fungsi pertukaran terdiri dari fungsi penjualan dan pembelian yang merupakan aktivitas perpindahan hak

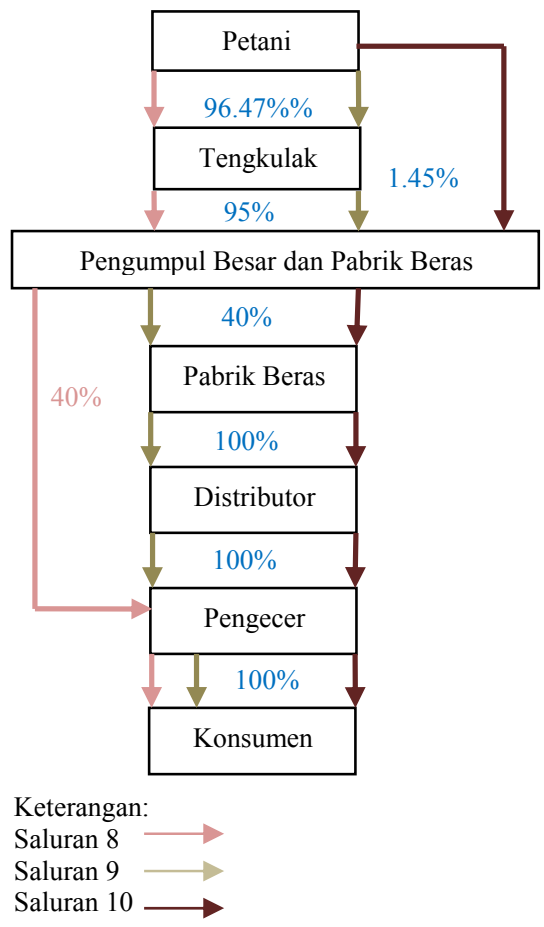

Gambar 3. Saluran Pemasaran Beras di Kecamatan Cibeber dengan Konsumen Akhir di Jakarta 
milik barang/jasa. Fungsi fisik terdiri dari fungsi penyimpanan, pengolahan, pengangkutan dan pengemasan sebagai aktivitas penanganan, pergerakan dan perubahan fisik dari produk/jasa dan turunannya. Fungsi fasilitas merupakan aktivitas yang memperlancar fungsi pertukaran dan fisik yang terdiri dari fungsi penanggungan risiko, pembiayaan, standarisasi dan informasi pasar. Pada penelitian ini, lembaga pemasaran pada setiap saluran menjalankan fungsi pemasaran seperti yang terdapat pada Lampiran 2.

\section{Analisis Struktur Pasar}

\section{Struktur Pasar di Tingkat Petani}

Struktur pasar di tingkat petani cenderung mendekati struktur pasar persaingan sempurna. Hal ini dilihat dari jumlah petani sebagai penjual GKP berjumlah banyak begitu juga jumlah pembeli. Beras sebagai kebutuhan pokok di Indonesia menjadikan permintaan akan hasil panen padi di tingkat petani juga tinggi. Selain itu, pangsa pasar masing-masing petani juga masih kecil terutama karena belum bekerjanya kelompok tani di tingkat petani sebagai lembaga pemasaran sehingga petani juga belum dapat mempengaruhi harga pasar.

Produk substitusi GKP sebenarnya masih sangat sulit, namun petani sebagai individu tidak mampu mempengaruhi harga pasar karena ukuran dan skala usaha petani sebagai individu kecil dan petani tidak melakukan perubahan produk sehingga pembeli GKP dapat berpindah secara mudah apabila petani menaikkan harga jual mereka. Untuk memasuki pasar juga cenderung mudah, artinya petani baru baik sebagai penggarap, penyewa, atau pemilik lahan dapat memperoleh keuntungan dalam setiap musim panen.

Hambatan keluar pasar juga tidak begitu sulit, artinya petani dapat beralih profesi karena faktor produksi utama yang dimanfaatkan oleh petani adalah lahan yang dapat dimanfaatkan dalam bentuk usaha lain. Petani juga tidak perlu mengeluarkan biaya lain apabila ingin beralih profesi apalagi petani di Cibeber belum menggunakan alat atau mesin pertanian modern yang mahal.

Informasi pasar mengenai persediaan dan harga GKP di Kecamatan Cibeber juga relatif mudah didapat oleh petani karena lokasi lahan dan tempat tinggal petani saling berdekatan, namun informasi harga terutama di konsumen akhir yang berada di Cianjur masih cukup sulit didapatkan petani. Petani melalui kelompok tani juga sering berkumpul dan mengadakan kegiatan berbagi informasi harga, teknik budidaya serta program pemerintah yang secara langsung maupun tidak langsung mempengaruhi petani padi di Cibeber tersebut.

\section{Struktur Pasar di Tingkat Tengkulak}

Dilihat sebagai pembeli, tengkulak cenderung oligopsoni terhadap petani. Hal ini berdasarkan jumlah tengkulak yang relatif lebih sedikit dibandingkan jumlah petani sebagai penjual hasil panen. GKP tetap merupakan produk yang belum terdifrensiasi secara baik. Sebagai pembeli juga terdapat hambatan yang cukup sulit terutama bagi tengkulak 
baru. Jaringan yang dibangun oleh tengkulak terhadap petani pada umumnya telah terbentuk dalam waktu yang sangat lama, bahkan berpuluhan tahun. Petani bahkan sering merasa tidak nyaman saat melakukan penjualan melalui tengkulak lain atau lembaga lain karena telah lama melakukan kerjasama dengan tengkulak yang tujuan penjualannya saat ini.

Informasi mengenai harga pembelian GKP oleh tengkulak kebanyakan hanya dipengaruhi informasi harga yang ditawarkan pengumpul besar atau RMU yang menjadi tujuan penjualan tengkulak tersebut selanjutnya. Dilihat sebagai penjual, tengkulak cenderung mendekati pasar persaingan sempurna. Jumlah tengkulak memang lebih sedikit daripada petani, namun sebenarnya jumlah tersebut lebih banyak dibandingkan jumlah lembaga tujuan penjualan tengkulak berikutnya. Tengkulak sebenarnya hanya sebagai pengambil harga yang menjadi tujuan penjualannya selama ini.

GKP yang disalurkan merupakan produk yang belum terdefrensiasi sehingga tengkulak masih sebgai penerima harga. Hambatan masuk pasar cukup sulit karena pada umumnya tengkulak juga merupakan orang kepercayaan yang telah lama bekerjasama dengan pengumpul besar atau pabrik beras. Kepercayaan terhadap tengkulak untuk menyediakan gabah secara berlanjut menyebabkan tengkulak mendapatkan harga pembelian yang lebih tinggi oleh pengumpul besar dan pabrik beras jika dibandingkan harga pembelian GKP oleh pengumpul besar atau pabrik beras di tingkat petani. Informasi pasar oleh tengkulak juga cenderung terbatas dari pengumpul besar dan pabrik beras atau dari RMU saja.

\section{Struktur Pasar di Tingkat RMU}

Struktur pasar di tingkat RMU baik sebagai pembeli maupun penjual berada pada pasar monopolistik. Hal ini berdasarkan jumlah RMU yang cukup banyak namun pangsa pasar setiap RMU relatif kecil. Produk yang disalurkan belum terdifrensiasi.

Hambatan menjadi RMU sebenarnya tidak begitu sulit apabila dilihat dari jumlah pembiayaan yang dijalankan atau mesin yang dimiliki. Namun, jaringan petani yang menjual hasil panennya kepada RMU cukup kuat meskipun harga pembelian yang dilakukan RMU lebih rendah daripada harga pembelian di tingkat pabrik yang lebih efisien. Informasi mengenai harga banyak dipengaruhi oleh harga di tingkat pengecer di pasar kecamatan maupun di pasar induk. Informasi untuk memperluas pangsa pasar oleh RMU sangat sulit diraihnya karena keterbatasan sumber daya yang dimiliki.

\section{Struktur Pasar Pengumpul Besar dan Pabrik Beras}

Sebagai pengumpul besar, struktur pasar yang dihadapi dari sisi pembeli maupun penjual adalah cenderung pasar persaingan monopolistik. Cukup banyak jumlah pengumpul besar yang membeli GKP dari petani dan menjualnya kembali ke pabrik beras yang skalanya lebih besar. Pengumpul besar memperoleh posisi tawar yang lebih baik ketika berhadapan dengan pabrik besar 
yang skalanya kecil karena pengumpul besar tersebut juga sebenarnya memiliki mesin pengolahan sendiri.

Harga pembelian GKP oleh pabrik beras yang skalanya lebih besar juga lebih tinggi terhadap pengumpul besar dibandingkan dengan harga pembelian di tingkat petani. Informasi pasar mengenai harga gabah dan beras di tingkat pasar sebenarnya juga didapatkan oleh pengumpul besar meskipun pada kenyataannya pengumpul tersebut tidak dapat mengolah dan memanfaatkan data tersebut karena ukuran dan pangsa pasar pengumpul besar yang masih rendah. Hambatan masuk sebagai pengumpul besar cukup sulit karena harus memiliki pembiayaan atau modal seperti alat transportasi sebagai alat pengangkutan hasil panen padi.

Pabrik beras yang sebelumnya merangkap sebagai pengumpul besar disini cenderung berada pada struktur pasar oligopsoni jika dilihat dari sisi pembeli. Hal ini disebabkan pabrik beras sekaligus pengumpul besar ini jumlahnya sebenarnya sedikit di setiap desa di Kecamatan Cibeber apalagi jika dibandingkan dengan jumlah tengkulak dan petani di desa tersebut. Hal tersebut menjadikan posisi tawar pabrik beras ketika membeli lebih kuat dan bahkan harga pesaing sesama pabrik yang paling besar mempengaruhi harga pembelian hasil panen oleh pabrik beras.

Hambatan menjadi pabrik beras juga cukup besar karena harus memiliki jaringan tengkulak, mesin pengolahan dan transportasi serta pembiayaan yang cukup dalam operasional pabrik. Informasi mengenai kesediaan gabah juga relatif baik dikuasai oleh pabrik beras karena memiliki jaringan tengkulak dan sesama pabrik beras. Dari sisi penjual, pabrik beras berada pada struktur pasar monopolistik. Hal ini disebabkan pabrik beras mempunyai alternatif saluran penjualan yakni ke grosir, pengecer atau bahkan hanya menjual gabah ke pabrik yang skalanya lebih besar dan lebih efisien. Meskipun memang setiap pabrik beras yang berada pada tingkat desa tidak dapat mempengaruhi harga keseimbangan pasar secara langsung, namun posisi tawarnya lebih baik dibandingkan dengan petani. Jumlah beras yang ditahan dan dijual oleh pabrik beras secara agregat dapat mempengaruhi tingkat harga.

\section{Struktur Pasar di Tingkat Pabrik Beras}

Sebagai pembeli maupun penjual pabrik beras cenderung menghadapi struktur pasar oligopsoni dan oligopoli. Sebagai pembeli, jumlah pabrik beras yang asetnya mencapai $\mathrm{Rp} 7$ milyar dalam penelitian sangat sedikit dibandingkan tujuan pembeliannya seperti petani, tengkulak, bahkan pengumpul besar dan pabrik beras yang dijelaskan sebelumnya. Hal ini mengakibatkan posisi tawarnya cukup kuat ketika berhadapan dengan penjual. Selain itu, pabrik beras juga mampu berproduksi dengan lebih efisien sehingga harga pembeliannya cukup tinggi.

Sebagai penjual, jumlah pabrik beras juga sangat sedikit apabila dibandingkan dengan jumlah distributor. Pangsa pasarnya cukup baik dan 
mencapai distributor diluar Cianjur. Gudang penyimpanan yang dimiliki cukup besar sehingga mampu mengatur tingkat penawaran ke tingkat distributor yang secara langsung akan mempengaruhi harga beras meskipun secara agregat nilai pengaruhnya masih sangat kecil. Pabrik beras juga dengan skala besar juga sangat mempertimbangkan keputusan harga yang ditetapkan oleh pabrik beras dengan ukuran besar di tempat lain.

Hambatan menjadi pabrik beras dalam penelitian ini sangat besar karena membutuhkan pembiayaan yang besar. Hambatan keluar juga cukup besar karena mesin yang harganya sangat mahal dan memiliki umur ekonomis rata-rata diatas 10 tahun.

\section{Struktur Pasar di Tingkat Distributor}

Distributor di Cianjur cenderung menghadapi struktur pasar monopolistik. Jumlahnya cukup banyak jika dibandingkan dengan dengan jumlah pabrik beras, namun, jika dibandingkan dengan pengecer jumlahnya memang lebih sedikit. Produk yang disalurkan merupakan beras yang subsitusinya masih dirasakan sulit di Indonesia, namun tetap saja karena beras yang dijual oleh distributor tidak mengalami perlakukan khusus sehingga pembeli dapat dengan mudah berpindah ke distributor lain apabila harga beras tidak mengikuti harga pasar.

Hambatan masuk adalah pembiayaan yang cukup besar ditambah modal lain seperti alat pengangkutan atau transportasi dan lokasi penyimpanan yang strategis. Hambatan keluar relatif lebih mudah karena tidak ada keterikatan usaha dan penggunaan mesin pengolahan. Informasi pasar didapat dari sesama distributor maupun kondisi di pengecer. Distributor di Cipinang cenderung pada oligopoli. Hal ini disebabkan fungsinya sebagai penyalur beras memiliki kapasitas besar bahkan penyimpanan mencapai ratusan ton. Hal ini meyebabkan terdapat kemampuan distributor ini mempengaruhi pasar dengan penentuan beras yang akan ditawarkannya ke pasar. Informasi pasar dapat dengan mudah didapat dari pengecer di pasar. Selain itu, distributor disini juga banyak dipengaruhi kebijakan pemerintah dalam penentuan harga jual meskipun secara tidak langsung.

\section{Struktur Pasar di Tingkat Pengecer}

Struktur pasar di tingkat pengecer, baik di Cianjur maupun Jakarta, cenderung mendekati pasar persaingan sempurna. Jumlah pengecer cukup banyak ketika berhadapan dengan distributor. Produk yang disalurkan adalah beras yang sebenarnya masih menjadi kebutuhan pokok di Indonesia, namun beras di masing-masing pengecer belum terdifrensiasi dengan baik. Hambatan masuk dan keluar cenderung mudah. Informasi pasar terutama berasal dari sesama pengecer atau dari pemasok beras kepadanya seperti distributor. Pengecer dengan pangsa pasar kecil adalah sebagai penerima harga keseimbangan dan pengecer tentunya berusaha menjual di harga keseimbangan yang berlaku di pasar. Apabila pengecer menjual dibawah harga keseimbangan, 
tentu membuat usahanya memperoleh keuntungan yang semakin kecil padahal beras yang dijual juga sedikit. Apabila pengecer menjual diatas harga keseimbangan, konsumen yang membeli kepadanya akan berkurang atau bahkan beralih ke penjual lain.

\section{Analisis Perilaku Pasar}

\section{Aktivitas Pembelian dan Penjualan}

Petani pada umumnya menjual gabah kering panen setelah melakukan pemanenan. Petani cenderung lebih menyukai menjual GKP dibandingkan GKG karena menginginkan uang tunai secepatnya. Tujuan penjualan petani adalah ke RMU, tengkulak, maupun pengumpul besar dan pabrik beras. Saat penjualan ke tengkulak, petani biasanya telah melakukan perjanjian ke tengkulak beberapa minggu sebelum masa panen agar tengkulak menjemput hasil panennya. Biaya pengemasan dan transportasi menjadi tanggung jawab tengkulak. Sistem tebas atau borongan juga sering dilakukan antara petani dan tengkulak. Antara petani petani dan tengkulak telah menyepakati harga pembelian hasil panen padi petani dimana aktivitas ini dilakukan sebelum masa panen. Biaya pemanenan biasanya menjadi tanggung jawab pemborong atau tengkulak. Hal ini sebenarnya dapat menyebabkan kerugian bagi petani atau tengkulak karena risiko produksi dan harga nantinya. Saat penjualan ke RMU atau pengumpul besar dan pabrik beras, petani dapat mendatangi langsung lembaga tersebut dan biaya taransportasi kini menjadi tanggung jawab petani.
Aktivitas penjualan tengkulak sendiri dilakukan ke RMU atau pengumpul besar dan pabrik beras. Pada umumnya, tengkulak telah melakukan kesepakatan harga beli oleh RMU atau pengumpul besar dan pabrik beras tersebut. Biaya transportasi, tenaga bongkar muat ke lembaga tujuan menjadi tanggung jawab tengkulak. Tengkulak pada umumnya telah menjadi mitra RMU atau pengumpul besar dan pabrik beras. Pada saat panen raya, biasanya tengkulak diberikan pinjaman modal untuk membeli hasil pembelian dari petani

Pembelian RMU sendiri biasanya berasal tengkulak, meskipun tetap ada yang berasal dari petani. Tujuan penjualannya adalah ke pengecer dan konsumen. Saat mengantarkan ke pengecer, biaya transportasi ditanggung oleh RMU sehingga harga jualnya lebih mahal dibandingkan ke konsumen yang langsung membeli ke lokasi RMU. RMU sendiri biasanya masih memiliki skala kecil dan hanya melakukan pembelian dan penjualan kepada lembaga yang jaraknya tidak begitu jauh dari lokasi RMU.

Pengumpul besar dan pabrik beras melakukan pembelian gabah dari petani dan tengkulak kemudian beras hasil olahan dijual ke pengecer atau distributor. Pada kondisi ini, semua biaya pengolahan dan pemasaran beras sampai ke pengecer atau distributor ditanggung oleh pengumpul besar dan pabrik beras. Pengecer atau distributor juga diberikan penawaran apabila ingin menjemput beras secara langsung. Biasanya terdapat kesepakatan harga yang berbeda apabila dijemput langsung 
oleh pengecer dan distributor. Sebagai pengumpul besar, GKP atau kadang diolah menjadi GKG oleh pengumpul besar, juga dijual ke pabrik beras yang skalanya lebih besar. Hal ini dilakukan karena kapasitas penggilingan pengumpul besar dan pabrik beras yang terbatas padahal lembaga ini biasanya mampu memperoleh gabah yang banyak karena lokasinya berada dekat dengan daerah atau lokasi petani.

Pabrik beras yang skalanya lebih efisien biasanya memiliki jaringan yang kuat. Sebagai pembeli, pabrik mampu membeli dengan harga lebih tinggi karena skala ekonominya yang lebih baik. Pembelian gabah bukan hanya dilakukan dari petani atau tengkulak sekitarnya, bahkan dari pengumpul besar dan pabrik beras yang berada di daerah tersebut dan daerah lain seperti Karawang. Tujuan penjualannya biasanya didominasi oleh distributor besar terutama yang berada di kota. Kualitas beras yang baik menjadi kekuatan pabrik beras dalam meyakinkan pembeli di kota-kota besar termasuk Jakarta.

Distributor melakukan pembelian dari pabrik beras dan melakukan penjualan ke konsumen termasuk pengecer. Distributor biasanya cukup selektif dalam memilih pabrik beras karena kualitas beras akan mempengaruhi penjualan distributor selanjutnya. Distributor yang semakin besar biasanya mampu melakukan penjualan dengan harga lebih rendah sehingga lebih disukai oleh pengecer.

Aktivitas pembelian pengecer berasal dari RMU, pengecer, pengumpul besar dan pabrik beras. Seluruh biaya pemasaran dan pengolahan sampai ke lokasi pengecer adalah tanggung jawab lembaga pemasaran sebelumnya. Pengecer biasanya berfokus pada penjualan ke konsumen langsung dan kebanyakan pengecer tidak hanya melakukan penjualan beras di kios atau lokas penjualannya. Terdapat juga pengecer yang menjemput langsung beras ke RMU dengan mempertimbangkan harga beli lebih murah padahal biaya transportasi sebenarnya tidak terlalu mahal.

\section{Aktivitas Penentuan Harga dan Sistem Pembayaran}

Penentuan harga oleh setiap lembaga pada sistem pemasaran beras di Kecamatan Cibeber menggunakan sistem tawar menawar, namun posisi tawar-menawar setiap lembaga pemasaran berbeda. Petani cenderung sebagai pengambil harga dari harga yang ditetapkan oleh tengkulak. Petani hanya dapat menawar sangat sedikit dari harga yang ditawarkan tengkulak dan harga tersebut memang hampir sama di setiap tengkulak.

Tengkulak juga menjadi pengambil harga ketika menjual gabah ke RMU, pengumpul besar dan pabrik beras dimana harga yang ditetapkan oleh lembaga ini biasanya telah memperhitungkan biaya pemasaran yang dilakukan oleh tengkulak. Tengkulak sebagai pengambil harga karena tengkulak tidak memiliki mesin pengolahan dan sumber daya yang memadai sehingga harus melakukan penjualan dalam waktu cepat. 
RMU, pengumpul besar dan pabrik beras memiliki kekuatan yang cukup baik ketika berhadapan dengan pengecer. Hal tersebut karena pengecer jumlahnya sangat banyak. Semakin besar ukuran dan skala penggilingan, posisi tawarnya semakin baik karena kualitas beras biasanya semakin baik. Namun, ketika berhadapan dengan distributor, setiap pabrik beras umumnya sangat mempertimbangkan harga yang ditetapkan oleh distributor apalagi jika kapasitas distributor semakin besar. Hal ini didasari anggapan bahwa distributor lebih memahami dan yang akan menanggung risiko harga beras yang cukup berfluktuatif.

Pabrik beras pada umumnya lebih mempertimbangkan jumlah permintaan saat ingin menjual ke distributor. Distributor cenderung sangat kuat dalam menentukan harga kepada pengecer. Pengecer hanya dapat mengikuti harga yang ditetapkan oleh distributor. Pengecer kemudian menjual beras dengan menetapkan harga penjualan ke konsumen dimana setiap harga jual yang ditetapkan oleh pengecer selalu memasukkan besarnya keuntungan yang diharapkan pengecer dan besarnya itu hampir selalu sama setiap waktunya di tingkat pengecer. Secara umum, fokus penetapan harga adalah untuk memaksimumkan volume transaksi lembagalembaga pemasaran mengingat banyaknya pelaku pemasaran lain yang menjadi saingan.

Sistem pembayaran yang paling mendominasi adalah sistem pembayaran tunai. Jumlah tengkulak yang banyak membuatnya berusaha meningkatkan kepuasan petani saat menjual kepadanya terutama karena petani sangat menginginkan uang tunai. Hampir di setiap lembaga menerapkan sistem pembayaran tunai untuk memberikan kepuasan, namun pembayaran distributor kepada pabrik beras sering menggunakan sistem tunda bayar yang membutuhkan waktu 3-7 hari. Pada musim panen raya, sistem tunda bayar juga sering terjadi di seluruh saluran karena penawaran yang tinggi sedangkan pembiayaan untuk pembelian dari lembaga tujuan penjualan tidak mengalami peningkatan yang signifikan.

\section{Kerjasama Lembaga Pemasaran}

Kerjasama sesama petani melalui kelompok tani masih hanya sebatas kerja bakti seperti pengadaan irigasi. Kelompok tani sendiri belum menjadi lembaga pemasaran yang dapat meningkatkan posisi tawar petani dengan skala usaha yang kecil. Kerjasama petani dengan tengkulak telah berlangsung cukup lama dan terdapat kebiasaaan hanya akan menjual melalui tengkulak. Kerjasama tengkulak dengan RMU, pengumpul besar dan pabrik beras dapat dilihat dari pinjaman yang digunakan tengkulak juga sebagai modal pembelian dari petani. Hal tersebut mengikat tengkulak untuk menjual hasil pembeliannya seluruhnya kepada RMU, pengumpul besar dan pabrik beras yang juga telah membantunya selama ini. Kerjasama di tingkat RMU, pengumpul besar dan pabrik beras dilihat bagaimana dari pengumpul besar gabah dijual lagi ke pabrik beras lain padahal pengumpul tersebut memiliki penggilingan. Sesama penggiling saling berbagi informasi dan 
jual-beli gabah juga sehingga dapat terus berproduksi. Lebih jauh lagi, penggiling atau pabrik beras saling berbagi informasi dan menyepakati harga pembelian gabah yang akan mereka lakukan. Pabrik beras juga sering memanfaatkan resi gudang sebagai bagian dari pemasaran untuk pengadaan modal dan penundaan penjualan dengan harapan harga penjualan yang akan lebih tinggi. Distributor dengan kapasitas besar saling bekerjasama untuk menentukan harga pembelian dan penjualan.

\section{Analisis Marjin Pemasaran}

Marjin pemasaran pada masing- masing lembaga secara sederhana merupakan selisih harga jual dan harga beli oleh lembaga tersebut seperti yang ditunjuukkan pada Tabel 1. Total marjin terbesar terdapat di saluran 9 dan 10, namun hal ini tidak dapat langsung memutuskan efisien atau tidaknya saluran. Hal tersebut harus mempertimbangkan fungsi dan manfaat masingmasing lembaga pemasaran.

\section{Analisis Farmer's Share}

Farmer's share merupakan salah satu indikator yang menunjukkan efisiensi operasional di tingkat petani berdasarkan perbandingan harga di

Tabel 1. Marjin Pemasaran pada Setiap Lembaga Pemasaran

\begin{tabular}{|c|c|c|c|c|c|c|c|c|c|c|}
\hline & \multicolumn{10}{|c|}{ Saluran Pemasaran } \\
\hline & 1 & 2 & 3 & 4 & 5 & 6 & 7 & 8 & 9 & 10 \\
\hline \multicolumn{11}{|l|}{ Tengkulak } \\
\hline Harga beli & 3.500 & & 3.500 & 3.700 & 3.700 & & & 3.700 & 3.700 & 3.700 \\
\hline Harga jual & 3.600 & & 3.600 & 3.800 & 3.800 & & & 3.800 & 3.800 & 4.000 \\
\hline Marjin & 100 & & 100 & 100 & 100 & & & 100 & 100 & 300 \\
\hline \multicolumn{11}{|l|}{ Penggiling } \\
\hline Harga beli & 3.600 & 3.600 & 3.600 & & & & & & & \\
\hline Harga jual & 8.300 & 8.300 & 8.500 & & & & & & & \\
\hline Marjin & 4.700 & 4.700 & 4.900 & & & & & & & \\
\hline \multicolumn{11}{|c|}{ Pengumpul besar dan pabrik beras di desa } \\
\hline Harga beli & & & & 3.800 & 3.800 & 3.700 & 3.700 & 3.800 & 3.800 & \\
\hline Harga jual & & & & 7.800 & 7.800 & 7.800 & 7.800 & 9.200 & 4.000 & \\
\hline Marjin & & & & 4.000 & 4.000 & 4.100 & 4.100 & 5.400 & 200 & \\
\hline \multicolumn{11}{|c|}{ Pabrik beras luar desa } \\
\hline Harga beli & & & & & & & & & 4.000 & 4.000 \\
\hline Harga jual & & & & & & & & & 8.700 & 8.700 \\
\hline Marjin & & & & & & & & & 4.700 & 4.700 \\
\hline \multicolumn{11}{|l|}{ Distributor } \\
\hline Harga beli & & & & 7.800 & 7.800 & 7.800 & 7.800 & & 8.700 & 8.700 \\
\hline Harga jual & & & & 8.200 & 8.200 & 8.200 & 8.200 & & 9.400 & 9.400 \\
\hline Marjin & & & & 400 & 400 & 400 & 400 & & 700 & 700 \\
\hline \multicolumn{11}{|l|}{ Pengecer } \\
\hline Harga beli & 8.300 & 8.300 & & 8.200 & & 8.200 & & 9.200 & 9.400 & 8.700 \\
\hline Harga jual & 8.500 & 8.500 & & 8.500 & & 8.500 & & 9.500 & 9.700 & 9.400 \\
\hline Marjin & 200 & 200 & & 300 & & 300 & & 200 & 300 & 700 \\
\hline Total Marjin & 5.000 & 4.900 & 4.800 & 4.800 & 4.500 & 4.800 & 4.500 & 5.800 & 6.000 & 6.000 \\
\hline
\end{tabular}


tingkat petani dengan harga di tingkat konsumen akhir. Tabel 2 yang menunjukkan farmer' share di setiap saluran pemasaran. Harga gabah di tingkat petani dan harga beras di tingkat konsumen pada Tabel 2 merupakan ratarata harga yang diperoleh dari responden. Saluran 1-7 merupakan saluran dengan konsumen akhir di Cianjur. Saluran 8-10 adalah saluran dengan konsumen akhir di Jakarta. Saluran 8, 9, dan 10 dimana konsumen akhirnya berada diluar Cianjur menunjukkan manfaat atau nilai tambah tempat yang lebih baik pada proses pemasaran.

Rasio keuntungan dan biaya yang menggambarkan keuntungan yang diperoleh masing-masing lembaga pemasaran pada setiap satuan rupiah biaya pemasaran yang dikeluarkan dapat dilihat pada Lampiran 3.

\section{Analisis Efisiensi Operasional Pemasaran}

Berdasarkan nilai marjin terkecil dan farmer's share terbesar pada saluran
7 yang melalui lembaga petani, pengumpul besar dan pabrik beras, distributor sampai ke konsumen. Secara tidak langsung, pada kondisi ini petani lebih diuntungkan karena proporsi harga yang diterimanya dibandingkan harga di tingkat konsumen lebih besar yakni 45,12\%. Hal ini karena distributor tidak melakukan diskriminasi harga terhadap pengecer maupun konsumen yang mau membeli beras di lokasi penjualan distributor. Namun, berdasarkan volume yang mengalir, hanya sekitar 10\% dari beras bndistributor yang dijual langsung ke konsumen akhir karena konsumen lebih sering melakukan pembelian di pengecer yang tidak hanya menjual beras saja. Distributor di Jakarta dalam penelitian juga ini tidak ada yang menjual ke konsumen akhir.

Berdasarkan rasio keuntungan terhadap biaya, saluran 8 yang melalui petani, pengumpul besar dan pabrik beras, pengecer sampai ke konsumen memiliki rasio yang cukup besar yakni 1,38. Rasio keuntungan terhadap biaya di setiap lembaga juga cukup merata.

\section{Tabel 2. Farmer's Share pada Setiap Saluran Pemasaran}

\begin{tabular}{cccc}
\hline Saluran & $\begin{array}{c}\text { Harga Gabah } \\
\text { di Petani } \\
\mathbf{( R p / K g )}\end{array}$ & $\begin{array}{c}\text { Harga Beras di } \\
\text { Konsumen Akhir } \\
\mathbf{( R p / K g )}\end{array}$ & $\begin{array}{c}\text { Farmer's } \\
\text { Share (\%) }\end{array}$ \\
\hline 1 & 3.500 & 8.500 & 41,17 \\
2 & 3.600 & 8.500 & 42,35 \\
3 & 3.500 & 8.500 & 41,17 \\
4 & 3.700 & 8.500 & 43,52 \\
5 & 3.700 & 8.200 & 45,12 \\
6 & 3.700 & 8.500 & 43,52 \\
7 & 3.700 & 8.200 & 45,12 \\
8 & 3.700 & 9.500 & 38,94 \\
9 & 3.700 & 9.700 & 38,14 \\
10 & 3.700 & 9.700 & 38,14 \\
\hline
\end{tabular}


Hal ini menunjukkan lembaga pemasaran pada saluran ini paling efisien berdasarkan tingkat rasio. Berdasarkan fungsi, saluran ini juga memberikan kepuasan pada konsumen akhir yang lebih baik dibandingkan saluran lainnya apabila dilihat berdasarkan nilai tambah tempat. Lembaga pemasaran pada saluran ini berusaha menyediakan dan menawarkan beras ke lokasi perkotaan yang berada cukup jauh dari lokasi pertanian dan pengolahan di Cianjur.

\section{KESIMPULAN}

Sistem pemasaran beras di Kecamatan Cibeber melibatkan 7 lembaga pemasaran diantaranya petani, tengkulak, penggiling, pengumpul besar dan pabrik beras dalam desa, pabrik beras dengan skala lebih besar luar desa, distributor dan pengecer. Setiap lembaga menjalankan fungsi pertukaran, fisik, dan fasilitas meskipun fungsi dijalankan dengan berbeda cara dan biaya. Terdapat 10 saluran pemasaran dan secara umum struktur pasar beras di Cianjur adalah oligopsoni.

Berdasarkan rasio keuntungan dan biaya, saluran 8 memiliki nilai rata-rata rasio yang besar yakni 1,38 dan rasio pada setiap lembaga juga cukup merata. Meskipun marjin pemasaran cukup besar dan farmer's sharenya juga lebih kecil dibandingkan saluran lain, namun saluran 8 dianggap paling efisien. Hal ini mempertimbangkan nilai output yang dihasilkan terhadap biaya dan proses pemasaran yang dilakukan dalam saluran 8 ini. Saluran 8 juga merupakan saluran yang dilalui perdagangan beras yang besar dibandingkan saluran yang lain, yakni 18,48 persen dari total perdagangan seluruh saluran. Saluran 8 terdiri dari Petani-Tengkulak-Pengumpul Besar dan Pabrik Beras-PengecerKonsumen (di Jakarta)

\section{SARAN}

Petani membutuhkan kelembagaan seperti kelompok tani dalam memasarkan hasil panennya. Hal ini diperlukan karena hasil panen masing-masing petani sedikit dan belum terdiferensiasi, sehingga posisi tawar petani rendah ketika berhadapan dengan lembaga pemasaran lain. Kelompok tani dibutuhkan untuk menghimpun hasil panen sehingga dapat meningkatkan posisi tawar petani. Selain itu, hasil panen yang terhimpun dapat membantu petani dalam memanfaatkan sistem resi gudang yang sudah ada di Cianjur.

Petani sebaiknya memasarkan hasil panennya ke pabrik dengan skala usaha dan jaringan pelanggan yang lebih luas. Harga beli pabrik tersebut akan lebih tinggi karena efisiensi usaha semakin baik.

\section{DAFTAR PUSTAKA}

Asmarantaka RW. 2012. Pemasaran Agribisnis (Agrimarketing). Institut Pertanian Bogor. Bogor.

Bassey NE, Ibok OW, Akapaeti AJ. 2013. Rice Market Structure, Conduct, and Peformance in Nigeria: A Survey of Akwa Ibom State Rice Marketers. Asian Journal of Agricultural and Food Science, 1(3). 
Baye M. 2010. Managerial Economics and Business Strategy Seventh Edition. McGraw-Hill Irwin. Singapura.

[BPS] Badan Pusat Statistik. 2014. Pengeluaran Penduduk Menurut Kelompok Makanan. http://www.bps.go.id. Diakses 24 Maret 2015.

. 2013. Jumlah dan Laju Pertumbuhan Penduduk. http://www.bps.go.id. Diakses 24 Maret 2015.

. 2013. Luas Panen, Produktivitas, Produksi Tanaman Padi Seluruh Provinsi. [internet]. http://www.bps.go.id/tnmn pgn.p hp. Diakses 17 Mei 2014.

. 2012. Statistik Indonesia. Badan Pusat Statistik. Jakarta.

Bupati Cianjur. 2012. Perwilayahan Komoditas Unggulan Tanaman Pangan dan Hortikultura. Pemerintah Daerah Cianjur. Cianjur.

Dahl, D.C, Hammond, I. 1977. Market and Price Analysis The Agricultural Industry. Draw-Hill, Inc. United States.

Dinas Pertanian dan Tanaman Pangan Kabupaten Cianjur. 2013. Hasil Laporan Produksi, Luas Lahan, Produktivitas, Harga Komoditi Padi. Disperta Cianjur. Cianjur.

. 2013. Profil Dinas Pertanian dan Tanaman Pangan Kabupaten Cianjur. Disperta Cianjur. Cianjur.
Kementrian Pertanian. 2014. Statistik Ekspor-Impor Komoditas Pertanian 2001-2013. http://pphp.pertanian.go.id/upload/ pdf/Jurnal Edisi Apr 14 1. Diakses 24 Maret 2015.

Kohls, R.L, Uhl, J.N. 2002. Marketing of Agricultural Products Ninth Edition. Prentice-Hall, Inc. New York. . 1990. Marketing of Agricultural Products Seventh Edition. Prentice-Hall, Inc. New York.

Melania. 2007. Struktur, Perilaku, dan Keragaan Pasar. Journal of Business and Management, 4(3).

Nurdiyah. 2014. Analisis Struktur, Perilaku, dan Kinerja Pemasraan Jambu Mete Gelondongan di Kabupaten Muna Provinsi Sulawesi Tenggara. [Tesis]. Program Pascasarjana. Institut Pertanian Bogor, Bogor.

Purcell. 1979. Agricultural Marketing: System, Coordination, Cash and Futures Prices. A Prentice-Hall Company. Virginia.

Sari. IN. Analisis Efisiensi Pemasaran Jagung di Provinsi Nusa Tenggara Barat. [Tesis]. Program Pascasarjana. Institut Pertanian Bogor, Bogor.

Sudiyono. 2002. Pemasaran Pertanian. UMM Press. Malang.

Sultana A. 2012. Rice Marketing in Bangladesh: From the Perspective of Village Study at Cox's Bazar District. African Journal of Agricultural Research, 7(45):5995-6004. 
Lokollo EM. 2012. Bunga Rampai

Rantai Pasok Komoditas Pertanian

Indonesia. Pusat Penelitian Sosial

Ekonomi dan Kebijakan Pertanian IPB. Bogor. 
Lampiran 1. Luas Panen, Produktivitas, Produksi Padi (GKG) serta Volume Impor Beras Indonesia Tahun 2009-2013

\begin{tabular}{|c|c|c|c|c|c|c|c|}
\hline \multirow{2}{*}{$\begin{array}{c}\text { Fungsi } \\
\text { Pemasaran }\end{array}$} & \multicolumn{7}{|c|}{ Lembaga Pemasaran } \\
\hline & Petani & Tengkulak & RMU & $\begin{array}{c}\text { Pengumpul } \\
\text { Besar }\end{array}$ & $\begin{array}{c}\text { Pabrik } \\
\text { Beras }\end{array}$ & Distributor & Pengecer \\
\hline \multicolumn{8}{|l|}{ Fungsi } \\
\hline \multicolumn{8}{|l|}{ Pertukaran } \\
\hline Beli & & $\checkmark$ & $\checkmark$ & $\checkmark$ & $\checkmark$ & $\checkmark$ & $\checkmark$ \\
\hline Jual & $\checkmark$ & $\checkmark$ & $\checkmark$ & $\checkmark$ & $\checkmark$ & $\checkmark$ & $\checkmark$ \\
\hline \multicolumn{8}{|l|}{ Fungsi Fisik } \\
\hline Simpan & $\checkmark$ & $\checkmark$ & $\checkmark$ & $\checkmark$ & $\checkmark$ & $\checkmark$ & $\checkmark$ \\
\hline Angkut & & $\checkmark$ & $\checkmark$ & $\checkmark$ & $\checkmark$ & $\checkmark$ & \\
\hline Olah & & & $\checkmark$ & $\checkmark$ & $\checkmark$ & & \\
\hline Kemas & $\checkmark$ & $\checkmark$ & $\checkmark$ & $\checkmark$ & $\checkmark$ & & $\checkmark$ \\
\hline \multicolumn{8}{|l|}{ Fungsi Fasilitas } \\
\hline Risiko & $\checkmark$ & $\checkmark$ & $\checkmark$ & $\checkmark$ & $\checkmark$ & $\checkmark$ & $\checkmark$ \\
\hline Modal & $\checkmark$ & $\checkmark$ & $\checkmark$ & $\checkmark$ & $\checkmark$ & $\checkmark$ & $\checkmark$ \\
\hline Standarisasi & & & $\checkmark$ & & $\checkmark$ & $\checkmark$ & $\checkmark$ \\
\hline $\begin{array}{l}\text { Informasi } \\
\text { Pasar }\end{array}$ & $\checkmark$ & $\checkmark$ & $\checkmark$ & $\checkmark$ & $\checkmark$ & $\checkmark$ & $\checkmark$ \\
\hline
\end{tabular}

Lampiran 2. Fungsi Pemasaran di Setiap Lembaga Pemasaran

\begin{tabular}{ccccr}
\hline Tahun & $\begin{array}{c}\text { Luas panen } \\
\text { (ha) }\end{array}$ & $\begin{array}{c}\text { Produktivitas } \\
\text { (ku/ha) }\end{array}$ & Produksi (ton) & $\begin{array}{c}\text { Volume impor } \\
\text { beras (ton) }\end{array}$ \\
\hline 2009 & 12.883 .576 & 49,00 & 60.325 .925 & 250.276 \\
2010 & 12.147 .637 & 50,15 & 66.469 .394 & 687.583 \\
2011 & 13.203 .643 & 49,00 & 65.756 .904 & 2.744 .261 \\
2012 & 13.445 .524 & 51,00 & 69.056 .126 & 1.927 .563 \\
2013 & 13.835 .252 & 51,52 & 71.279 .709 & 472.675 \\
\hline
\end{tabular}


Lampiran 3. Total Rasio Keuntungan dengan Biaya Pemasaran pada Setiap Saluran Pemasaran

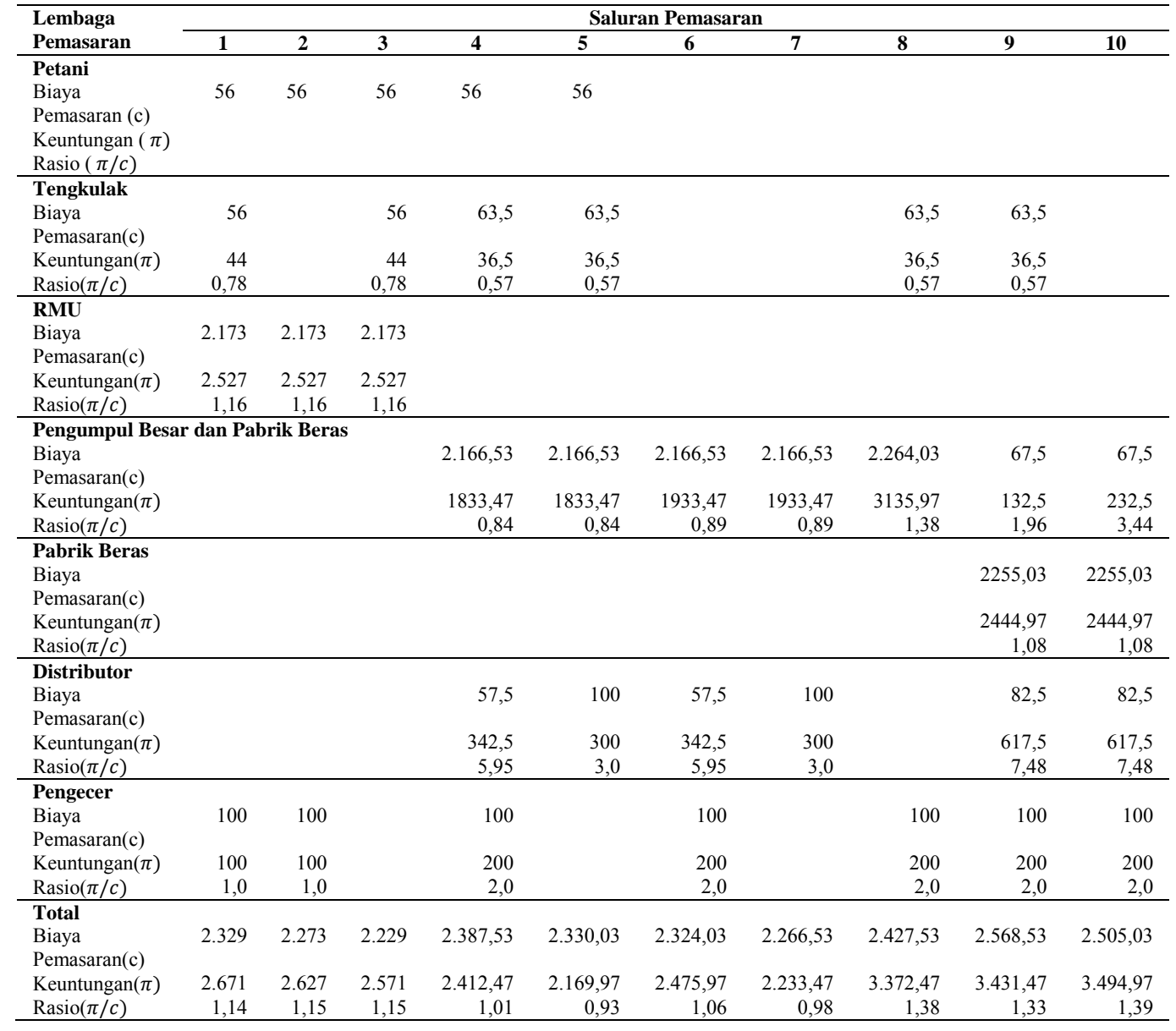

